\title{
ROLE OF NATURAL ENEMIES AND MICROBIAL CONTROL FOR CONTROLLING RED PALM WEEVIL , Rhynchophorus ferrugineus OLIVER AT DAKAHLIA GOVERNORATE,EGYPT.

\author{
Saleh, A. A. ${ }^{1}$ \\ M. M. Elbarbary ${ }^{2}$ \\ A. A. Abd-Elhady ${ }^{2}$; M. K. Abas ${ }^{1}$ and \\ 1- Pesticides Department, Fac. of Agricultural, MANSOURA Univ., \\ 2-Plant Protection Res., Inst., Agric. Res. Center, AL-Dokky, Giza, Egypt.
}

\begin{abstract}
The red palm weevil (Rhynchophorus ferrugineus) is a devastating pest of palms in the Mediterranean, Middle East, and Eastern countries. Survey the natural enemies were conducted during two successive years (2009and 2010) in Dakahlia governorate. The RPW in date palm has been managed with an integrated pest management (IPM) approach comprising several tactics including the biopesticides based on insects, mites, predators to control. In this study, the susceptibility of different date palm cultivars to the RPW infestation was determined and a survey of the natural enemies of the RPW in Dakahlia governorate was conducted. The obtained results showed that red palm weevil inside cocoons stages were attacked by the ectoparasitoids mites; Uropodina phoritic and Aegyptus rhynchophorus. On the other hand recorded local strain of Beauveria bassiana mycosis disease on RPW was verified. Also Anisolabis maritime predator eggs of the RPW.

The parasitism showed three peaks each year. The high parasitism of the mites start with in the beginning of January then increased gradually to reach the first peak at the $4^{\text {th }}$ week of January, $2^{\text {nd }}$ week of February and $2^{\text {nd }}$ week at April these peaks were recorded during 2009. Also during season 2010 the first peak at the $2^{\text {nd }}$ and $4^{\text {th }}$ weeks of March and $2^{\text {nd }}$ week of April. Also the pathogenic fungus $B$. bassiana exhibited three peaks of seasonal activity each year. These peaks were recorded during 2009 in February, March and May. While, the second season (2010), of activity was recorded from the January to the June and these peaks were recorded in February, April and May. Data indicated that there was significant positive correlation between average temperature and the parasitism. So it's with the pathogenic fungus, abundance on the RPW, the studied two year. While relative humidity had negative effect.

Keywords: Biological control; pathogenic fungus; parasitism; predator eggs; natural
\end{abstract} enemies.

\section{INTRODUCTION}

The red palm weevil (RPW) Rhynchophorus ferrugineus Olivier, 1790 (Coleoptera: Curculionidae) is one of the most severe pests of various palm species, including date palms. The red palm weevil larvae develop within the tree trunk destroying its vascular system and eventually causing the collapse and death of the tree. Red palm weevil (RPW) $R$. ferrugineus is the most destructive and dangerous pest attacking palm trees in many countries in Asia and the middle East. It caused mass destruction in date palm in Egypt and the Gulf countries. It also attacks coconut trees, oil palm through 
Saleh, A. A. et al.

Southeast Asia (Kalshoven, 1950). Red palm weevil was accidentally introduced for the first time to the Gulf region, since its appearance in United Arab Emirates in 1985, then Saudi Arabia on 1986, Iran in 1992, Egypt 1993, Jordon in 1998 and Israel in 1999 (Abraham et.al., 1998, Murphy and Briscoe 1999, Soroker et.al., 2005).They are found over a very wide geographical area involving different climates. The biological control of the red palm weevil, A naturally occurring entomopathogenic fungus has been found adults and pupae of red palm weevil in several date palm plantations in ARE. It was isolated for the first time by the biological control project of RPW and identified by scientific collage Mansoura University. The fungus was found to be potentially important as biological control agent of red palm weevil. The fungus was designated in Dakahlia Governorate of ARE as a local strain of Beauveria bassiana .

Also surveys for natural enemies of the Red Palm Weevil $R$. ferrugineus was studied using the local strain, the entomopathogenic fungus B.bassiana in Egypt. Investigated the red palm weevil, $R$. ferrugineus is the major destructive insect pest of date palm trees in Middle East. Dependence on chemical control constitutes a major constrain to develop an IPM strategy, because of resistance problems, disruptive effects on natural control of secondary pests and pesticide residue on fruits (Sewify et al., 2009). Knowledge of both its natural enemies and its defensive mechanisms against predators and microorganisms is important to develop methods for an integrated pest control (Mazza et. al., 2011).

In this study, determined the RPW in date palm has been managed with an integrated pest management (IPM) approach comprising several tactics including the biopesticides based on insects, mites(Acarina: Uropodidae, Uropodidina phoritic) predators and microorganisms to control the RPW , FAO,1996; EL-Bishry et al., 2000 and Deadman et al., 2001. In this study, the susceptibility of different date palm cultivars to the RPW infestation was determined and a survey of the natural enemies of the RPW was conducted. In addition, the natural and artificial incidence of $B$. bassiana mycosis disease on RPW was verified (SHarshir et. al., 2006).

Also Anisolobis maritime predator eggs of the RPW. Atakan et al. (2009) mentioned that Phoretic mites (Acarina: Mesostigmata: Uropodidae) were identified on the red palm weevil (RPW). EL-Bishlawy and Allam (2007) in Egypt, found that a new mite Aegyptus rhynchophorus, N. GEN., N.SP. (ACARI:gamasida: trachyurodidae) collected from cocoons, pupae and adults of $R$. ferrugineus, very effected on RPW inside cocoons stages, while were carried and very low effected on RPW adults.

\section{MATERIALS AND METHODS}

\section{1- Field experiments:}

An area of 5000 tree palms covered with different date palm cultivars (Samany, Zaghlol and other date palms) at Dakahlia region was chosen to survey the incidence of the Red palm Weevil $R$. ferrugineus (RPW) and its associated natural enemies for two year (2009-2010). Weekly, 
orchards of the palm cultivars were visited. In each visit, twenty five trees of each cultivar were randomly chosen as a sample to be examined for RPW infestation. Each cultivar was represented by three samples. The visited orchards included different date palms ages. As a concealed tissue borer and its life stages of RPW are found inside the palm trees.

Each visit, the highly infested trees were shopped and all stages of the RPW, expect eggs, were carefully gathered. Every sample consisted of 100 cocooned stages (adult, pupa) and 100 larvae. The collected specimens were directly put in separated sterilized jars and transferred to the laboratory. Under aseptic conditions, the RPW individuals were maintained and examined for viability. The natural mortality percentages were estimated and the noticed insect and mite natural enemies were observed, separated under a binocular stereoscopic microscope and identified at both (Department of Economic Entomology and Department of Agricultural Microbiology at Mansoura. To full estimate of $B$. bassiana natural infection, further incubation of the naturally dead individuals was performed in damp chambers as described. The RPW individuals covered with flat white mycelial growth bearing mealy white conidia were considered, and microscopic preparations were used to assure the specific characteristics of B.bassiana (Balsamo) Vuilemin recorded by (Domsch et. al., 1980). Percentages of the natural infection by $B$. bassiana on the dead individuals were calculated.

The insect predators observed on the collected samples were counted and recorded as field observations. As

shown in Figures (1,2 and 3 ). The natural enemies associated of the red palm weevil.
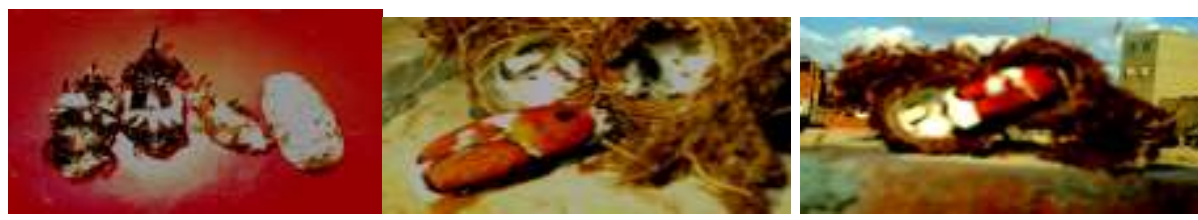

Figure (1).Entomopathogenic fungus ( Beauveria bassiana) activity on ( RPW) population.
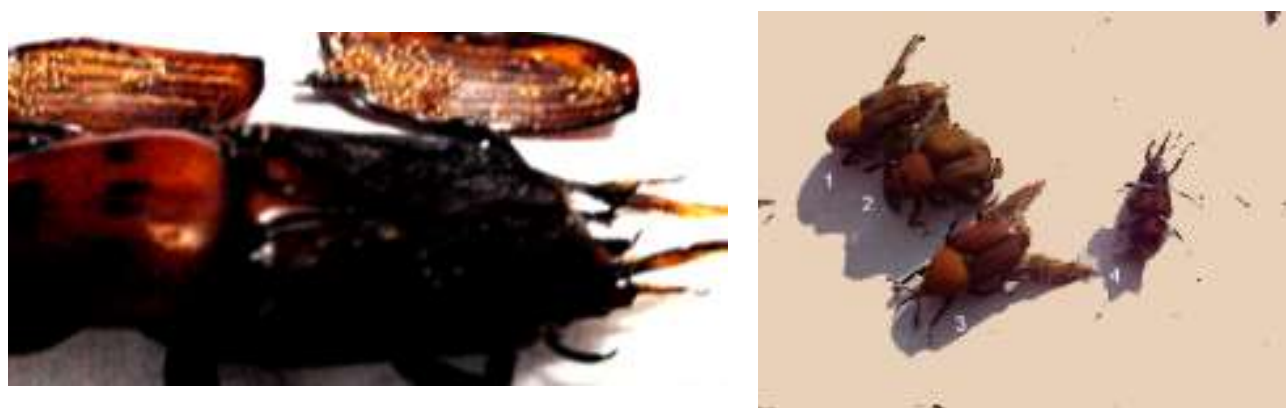

Figure (2).Parasitoid mite (Uropodina phoritic) activity on red palm weevil population 
Saleh, A. A. et al.
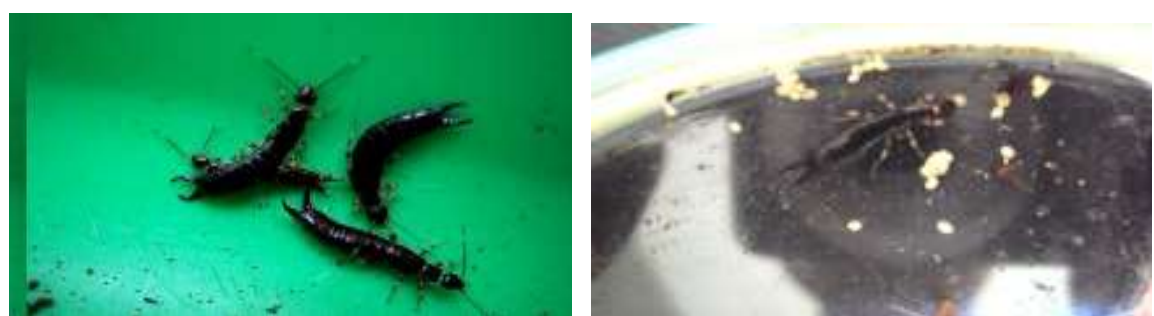

Figure (3).Predator ( Anisolabis maritime )activity on red palm weevil ( RPW) population .

2- Evaluation the role of the natural enemies:

\section{2-1- Entomopathogenic fungi:}

The collected samples were investigated and each red palm weevil larval, pupal and adult species was counted.

Living and dead individuals from each sample which show general infected symptoms were distinguished and put into sterilized tubes throughout the two studied seasons. The collected tubes were transferred to the Microbiological Lab., (Microbiology Department, Faculty of Agriculture, Mansoura University) to isolate and identify fungi species presented on the tested pest.

All damaged individuals were counted and the percentage of infected larvae or (pupal and adult) (Diseased \%) was calculated as follows:-

$$
\text { Diseased \% }=\frac{\mathrm{N}_{\text {dis. }}}{\mathrm{N}_{\mathrm{L}}+\mathrm{N}_{\mathrm{d}}}
$$

Where, $N_{\text {dis. }}$ is the number of diseased individuals. While, $N_{L}$ and $N_{d}$ are the numbers of living and dead individuals.

\section{2-2- Parasitoids and predators:}

To estimate the role of parasitoids and predators on red palm weevil (eggs, larvae, pupa and adults), and then investigated under stereomicroscope. All stages were recorded as living, dead (involved predated individuals) and parasitized with living parasitoids.

To determine the parasitoid species, each sample was maintained in Petri dishes (10 cm in diameter), containing a piece of moistened cotton wool. The emerged parasitoids were collected and identified.

The percentage of parasitism (Par. \%) was calculated as follows:-

$$
\text { Par. \% }=\frac{N_{\text {Par. }}}{N_{L}+N_{d}}
$$

Where, $N_{\text {Par. Is }}$ Ise number of parasitized individuals. While, $N_{L}$ and $\mathrm{N}_{\mathrm{d}}$ are the numbers of living and dead individuals.

Daily records of mean temperatures along with relative humidity obtained from the Agrometeorological station at Dakahlia governorate to represent the climatic conditions effect, during 2009 and 2010. 


\section{II- Laboratory experiments:}

\section{1-Isolation and identification of fungus:}

The dilution plate method was used for the isolation of the insect fungus. The fungus has been found infecting adults and pupae of red palm weevil in several date palm plantations in AL-Dakahlia region. It was isolated for the first time by Microbiological Department, Agriculture College, Mansuora University and identified in Unit of Microbiological Analysis (UMA) of Science College, Mansora University. To full estimate of $B$. bassiana natural infection. RPW individuals covered with flat white mycelial growth bearing mealy white conidia were considered, and microscopic preparations were used to assure the specific characteristics of $B$. bassiana.

\section{2- Preparation of inoculums:}

The B. bassiana isolates from RPW pupae stages was tested in the first screening. Fungus was grown for 2 weeks at $25^{\circ} \mathrm{C}$ on Sabouraud dextrose agar (Difco). Spores were harvested by washing the dishes with an aqueous solution of $0.01 \%$ Triton X-100.; Spore concentration was

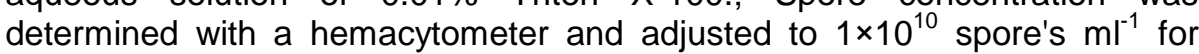
egg, larval and adult bioassay. In order to obtain a dry spore formulation. B. bassiana isolated was grown on a solid rice based medium for 3 weeks and dried at $32^{\circ} \mathrm{C}$. The procedure was as follows: rice washed in cold running water was mixed with water and sunflower oil $(500 \mathrm{ml}$ of water and $20 \mathrm{ml}$ of oil per $\mathrm{kg}$ of rice). Before sterilization in an autoclave, rice was heated until water had been absorbed. The autoclave rice was inoculated with $25 \mathrm{ml}$ spore suspension $\left(10^{10}\right.$ spore $\left.\mathrm{ml}^{1}\right)$. Inoculated rice was incubated at $28^{\circ} \mathrm{C}$ for 2-3 weeks until sporulation. subsequently, bags were opened and rice with spores was dried in a ventilated chamber at $30-32^{\circ} \mathrm{C}$ for 7 days so slants were scraped, using $5 \mathrm{ml}$ sterile tap water, then transferred to a flask containing $300 \mathrm{ml}$ sterile (PDA). The resulting spore suspensions (contain 1 $\mathrm{X} 10^{10}$ spore $\mathrm{ml}^{1}$.) were used for inoculation.

As shown in Figure (4). B. bassiana isolated was grown on a solid rice based medium.
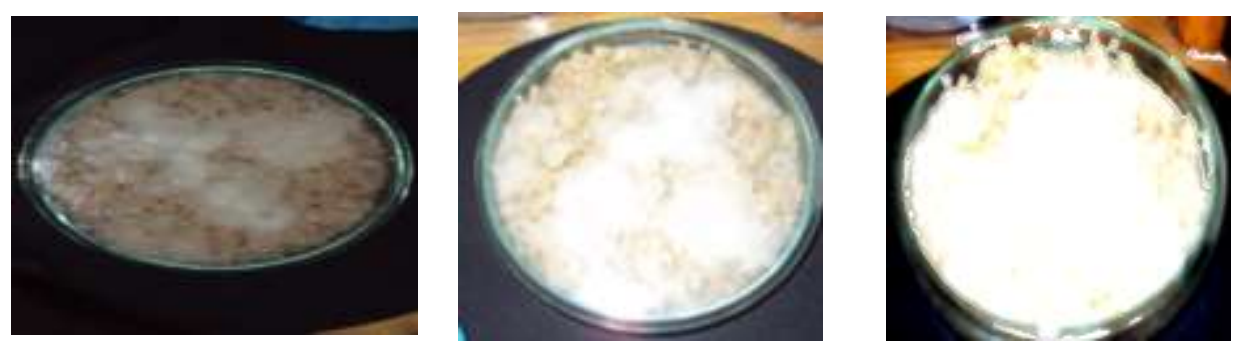

Figure (4): Beauveria bassiana isolated was grown on a solid rice based medium. 
3- Pathogenicity and efficiency of microbial isolates.

3-a- The effects of the isolates fungus on eggs and hatched larvae of RPW.

3-b- The effect of isolates fungus on the egg stage:

Five dilutions of prepared inoculums in distilled water were prepared as follow: $1 \times 10^{6}, 1 \times 10^{7}, 1 \times 10^{8}, 1 \times 10^{9}$ and $1 \times 10^{10}$ spore / ml. Strips of muslin on which the eggs had been laid (containing 20 eggs 1-3 days old each) were dipped for two seconds in each of the suspensions. In each dilution treatment 0.025 Tween 100X was used. After dipping, treated and untreated water as control strips were left to allow the excess moisture to dry out, then the eggs were placed in plastic boxes $(3.5 \times 12 \mathrm{~cm})$ each containing $5 \mathrm{~g}$ sugar cane sawdust pretreated and held at laboratory conditions until hatch. Five replicates of each treatment were used for each inoculums suspension.

The treated and untreated eggs were investigated daily until hatching. Hatchability percentages of treated and untreated eggs were calculated.

Larvae hatched from treated and untreated eggs were then individually put in placed in plastic boxes $(15 \times 35 \mathrm{~cm})$ containing sugar cane logs and was tightly closed by a plastic cover until pupation and adult emergence. Percentages of larval, pupal mortality and malformed pupae and also adult were calculated .As shown in Figure (5).

The percentage of efficacy (E \%) was calculated by using (Henderson and Tilton) equation (1952) formula.

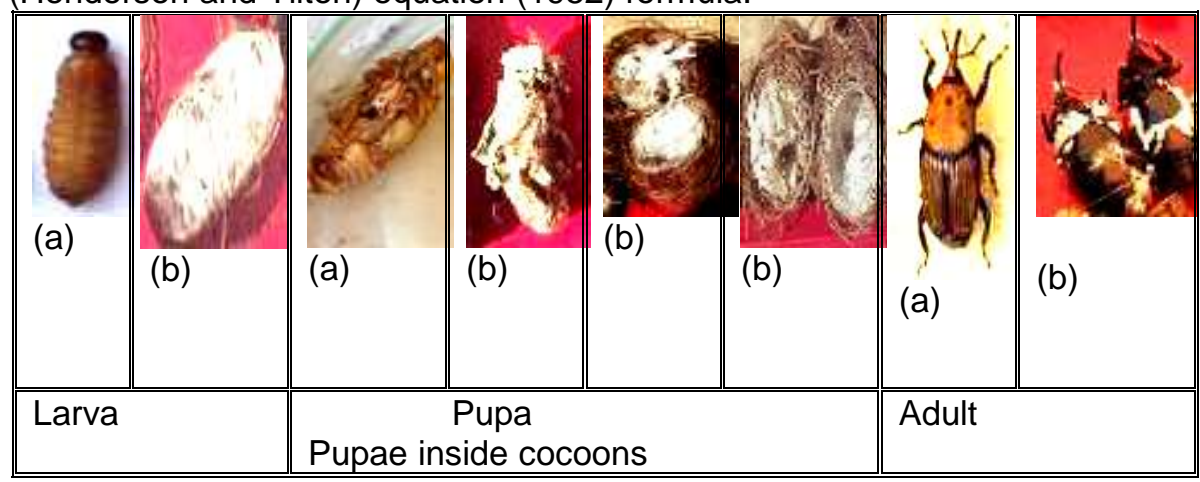

Figure (5).Normal (a) and abnormal larval, pupae mortality and malformed pupae and also adult (b) resulted

from (RPW) stages infected with pathogenic fungus Beauveria bassiana.

3-c- The effect of fungus isolated on larval, pupae and adults stage:

The previously mentioned five dilutions were bioassay against the newly hatched larvae, medium and last instars" larvae and pupae and adults of the RPW by fungal conidia produced on natural mycosed weevils were used to prepare a suspension containing $1 \times 10^{6}, 1 \times 10^{7}, 1 \times 10^{8}, 1 \times 10^{9}$ and $1 \mathrm{x}$ $10^{10}$ conidia/ml of sterilized $0.1 \%$ Tween 20 water solution, contaminate by dipping them individually for 3 seconds in the suspension. Also individuals 
dipped in sterilized $0.1 \%$ Tween 20 water solution served as check treatment. Each treatment was twenty newly hatched larvae, medium and last instars" larvae and pupae and adults of the RPW and replicated 5 times. The treated individuals were placed in sterilized plastic boxes $(20 \times 40 \mathrm{~cm}$.) each containing with fresh pieces of sugar cane recommended by (Rahalkar and Rananavare ,1972) for RPW rearing. Hatched larvae were transferred to other plastic boxes $(20 \times 40 \mathrm{~cm}$.). On the other hand individuals were dipped in distilled water and used as controls.

\section{RESULTS AND DISCUSSION}

\section{Parasitoid activity on red palm weevil (RPW) population.}

During the investigation period of the two years of study, two parasitoid species were found and recorded on red palm weevil last larvae, pupae, adults in cocoons and emergence adults, belong to Classes Acarina. Those parasitoids were the ectoparasitoids, Uropodina phoritic and Aegyptus rhynchophorus.

The seasonal activity of the ectoparasitoid, mites on RPW responded to mean temperature but not to relative humidity.

As shown in figure (6), the parasitoid exhibited approximately the same trend of activity as in the two years. In the first season (2009), $U$. phoritic and A. rhynchophorus, activity started to attack RPW at the January and then slightly increased gradually till the February which the percentage of parasitism reached $38 \%$ and decreased gradually till August. Then, the parasitoid activity started at September as the percentage of parasitism was $11 \%$ and increased gradually to the end of the season. While, in the second season (2010), the parasitoid activity started at the January till March which the percentage of parasitism reached $84 \%$ decreased gradually till the July. Then, the parasitoid activity started at August, the percentage of parasitism was $5 \%$ and increased gradually to the end of the season.

Data obtained during two successive years (2009 and 2010) indicated that the full-grown larvae of red palm weevil inside cocoon attacked by the ectoparasitoids mites, U. phoritic and A. rhynchophorus at Dakahlia region. These species attacked red palm weevil stages inside cocoons, pupae and adults at the all seasons with abundance numbers in winter season. These finding are agree with those of (Peter, 1989; Murphy and Briscoe, 1999; EL-Bishlawy et al., 2007\& Mazza et al., 2011).

These parasitoid exhibited high activity (parasitism \%) on RPW population during both seasons (2009 and 2010). According to (Abdullah, 2009) parasitoids were very much important in controlling (RPW) pests on date palms. Also (Atakan et al., 2009), found that mean total numbers of mites in the date palm trees in February.

Added that the rates of parasitism on red palm weevil stages are very low during summer seasons, while increase gradually in winter during formed of cocoon and malformation of the adults during pupae molting when are wings white colors. This might indicate that the parasitoids can easily reach to their host in winter seasons where formed of cocoon, period of the generation 
was the largest and the activity of the parasite. On the other hand the parasitism in seasonal 2010 more than 2009.

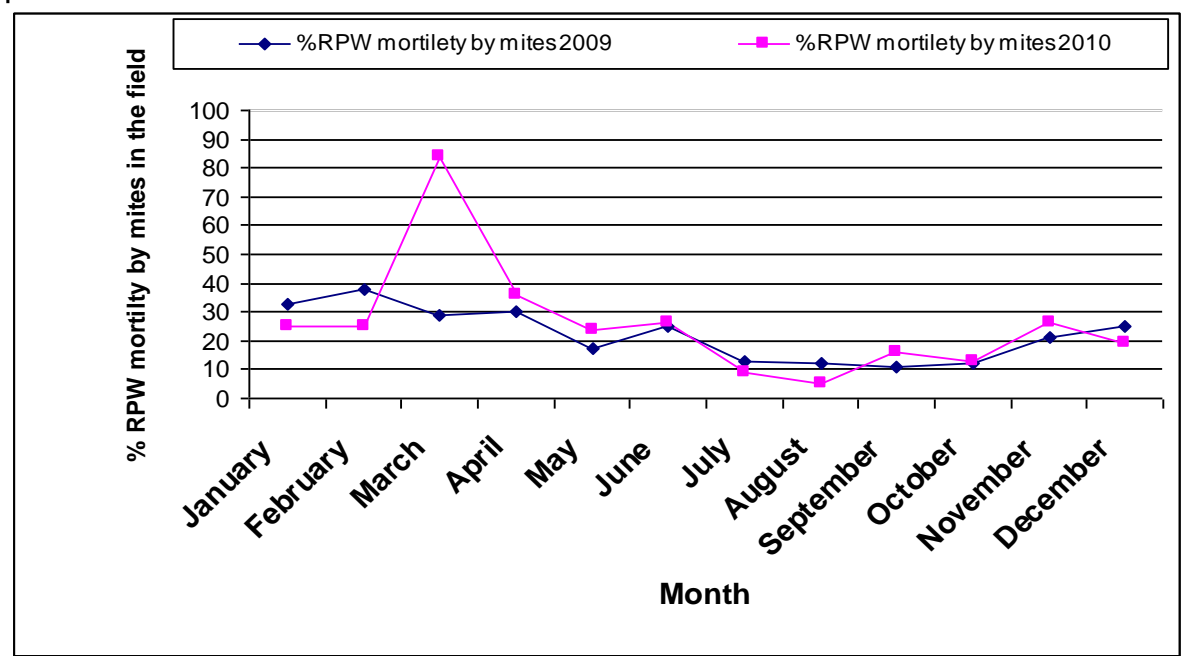

Figure (6): Seasonal activity of the mites Uropodina phoritic and
Aegyptus rhynchophorus these

Associated with (RPW) during seasons 2009 - 2010 at Dakahlia governorate.

The effect of weather factors on activity of the parasites (mites) on red palm weevil $\boldsymbol{R}$. ferrugineus populations during 2009.

Data presented in Table (1) showed the parasites (mites) on RPW is existed all over the year and there peaks all over the year 2009, the mean of total high parasitism start with in the beginning of January then increased gradually to reach the first peak at the $4^{\text {th }}$ week of January, $2^{\text {nd }}$ week of February and $2^{\text {nd }}$ week April $(13.75,15.75,14.75)$ respectably. Also parasite was carried on (RPW) adult's stage of the range. Also it is law parasitism with highly temperature but negative with humidity reason in palm high moister and rain in winter season. On the other hand period activity parasitism synchronization decreased activity of (RPW). ((EL-Lakwah et .al (2011) in Egypt evaluated the present work aims to study the population dynamics of RPW R. ferrugineus adults in relation to certain climatic factors using attracting pheromone traps on date palm plantation. Experiments were conducted during two successive years (2009and2010). The diurnal flying activity of RPW was also considered. The obtained results showed that adults emerging continually throughout the year. The lowest adult's population was recorded during December and January. The population showed four peaks each year. There were four peaks each of emergence during 2009 at $2^{\text {nd }}$ week of April, $1^{\text {st }}$ week of June, $1^{\text {st }}$ week of August and $2^{\text {nd }}$ week of November. Data indicated that there was significant positive correlation between average temperature and adult's population abundance of the RPW the studied two year. While relative humidity had negative effect)). 
Data presented in Table (2) showed the parasites (mites) on RPW is existed all over the year and there peaks all over the year 2010, the mean of total high parasitism start with in the beginning of January then increased gradually to reach the first peak at the $2^{\text {nd }}$ and $4^{\text {th }}$ weeks of March, $2^{\text {nd }}$ week of April $(37.75,19.50,14.75)$ respectably. Also parasite was carried on RPW adult's stage of the range. Also it is law parasitism with highly temperature but negative with humidity, reason in palm high moister and rain in winter season. On the other hand period activity parasitism synchronization decreased activity (RPW).

Table (1).The effect of weather factors on activity of the parasites (mites) on (RPW) during 2009.

\begin{tabular}{|c|c|c|c|c|c|c|c|}
\hline \multirow[b]{2}{*}{$\begin{array}{c}\text { Inspection } \\
\text { Date }\end{array}$} & \multicolumn{5}{|c|}{ Average of (RPW) stages effected by parasite } & \multicolumn{2}{|c|}{ Mean } \\
\hline & Eggs & $\begin{array}{l}\text { Active } \\
\text { larvae }\end{array}$ & $\begin{array}{l}\text { Stages } \\
\text { inside } \\
\text { cocoons }\end{array}$ & $\begin{array}{l}\text { Parasite } \\
\text { carried } \\
\text { on adult }\end{array}$ & total & $\begin{array}{c}\text { Temperature } \\
\mathbf{C}^{0}\end{array}$ & $\begin{array}{l}\text { Humidity } \\
\text { (RH) }\end{array}$ \\
\hline 15-Jan-2009 & 0.00 & 0.00 & 9.75 & 4.25 & 14.00 & 11.6 & 61.5 \\
\hline 31-Jan-2009 & 0.00 & 0.00 & 13.75 & 5.25 & 19.00 & 13.6 & 59.3 \\
\hline 15-Feb-2009 & 0.00 & 0.00 & 15.75 & 6.25 & 22.00 & 13.7 & 61.0 \\
\hline 28-Feb-2009 & 0.00 & 0.00 & 10.75 & 5.25 & 16.00 & 12.0 & 61.2 \\
\hline 15-Mar-2009 & 0.00 & 0.00 & 9.75 & 7.25 & 17.00 & 20.8 & 58.7 \\
\hline 31-Mar-2009 & 0.00 & 0.00 & 7.75 & 4.25 & 12.00 & 20.6 & 60.3 \\
\hline 15-Apr-2009 & 0.00 & 0.00 & 14.75 & 3.25 & 18.00 & 19.7 & 63.7 \\
\hline 30-Apr-2009 & 0.00 & 0.00 & 7.75 & 4.25 & 12.00 & 23.1 & 64.4 \\
\hline 15-May-2009 & 0.00 & 0.00 & 3.00 & 2.00 & 5.00 & 26.5 & 63.3 \\
\hline 31-May-2009 & 0.00 & 0.00 & 8.75 & 3.25 & 12.00 & 25.8 & 60.6 \\
\hline 15- Jun -2009 & 0.00 & 0.00 & 10.75 & 4.25 & 15.00 & 26.2 & 57.9 \\
\hline 30-Jun -2009 & 0.00 & 0.00 & 6.75 & 3.25 & 10.00 & 28.8 & 61.1 \\
\hline 15- Jul -2009 & 0.00 & 0.00 & 5.75 & 2.25 & 8.00 & 28.0 & 66.1 \\
\hline 31- Jul -2009 & 0.00 & 0.00 & 3.75 & 1.25 & 5.00 & 26.8 & 65.3 \\
\hline 15-Aug-2009 & 0.00 & 0.00 & 4.50 & 1.50 & 6.00 & 25.0 & 67.1 \\
\hline 31-Aug-2009 & 0.00 & 0.00 & 4.25 & 1.75 & 6.00 & 24.3 & 67.8 \\
\hline 15-Sep-2009 & 0.00 & 0.00 & 5.25 & 0.75 & 7.25 & 26.9 & 65.3 \\
\hline 30-Sep-2009 & 0.00 & 0.00 & 7.25 & 1.75 & 8.00 & 27.3 & 63.5 \\
\hline 15-Oct-2009 & 0.00 & 0.00 & 3.00 & 1.00 & 4.00 & 21.6 & 62.8 \\
\hline 31-Oct-2009 & 0.00 & 0.00 & 7.00 & 1.00 & 8.00 & 20.1 & 63.3 \\
\hline 15-Nov-2009 & 0.00 & 0.00 & 6.00 & 4.00 & 10.00 & 18.9 & 65.3 \\
\hline 30-Nov-2009 & 0.00 & 0.00 & 7.75 & 3.25 & 11.00 & 16.4 & 71.5 \\
\hline 15-Dec-2009 & 0.00 & 0.00 & 7.50 & 2.50 & 10.00 & 15.3 & 67.9 \\
\hline 31-Dec-2009 & 0.00 & 0.00 & 9.25 & 5.75 & 15.00 & 16.2 & 70.4 \\
\hline \multirow[t]{2}{*}{ total } & & & 190.50 & 79.75 & 270.25 & \multirow[b]{2}{*}{21.22} & \multirow[b]{2}{*}{63.7} \\
\hline & & & 7.94 & 3.32 & 11.26 & & \\
\hline
\end{tabular}

During the investigation period of the two years of study, entomopathogenic fungus species was found and recorded on the red palm weevil (last larvae, pupae, adult) in cocoons and emergence adults. This entomopathogenic fungus was the Beauveria bassiana (Balsamo).

The seasonal activity of the fungus $B$. bassiana, on RPW in response for the first and second seasons (2009-2010) on date palm tree infested by RPW. 
Saleh, A. A. et al.

Table (2).The effect of weather factors on activity of the parasites (mites) on (RPW) during 2010.

\begin{tabular}{|c|c|c|c|c|c|c|c|}
\hline \multirow[b]{2}{*}{$\begin{array}{l}\text { Inspection } \\
\text { Date }\end{array}$} & \multicolumn{5}{|c|}{ Average of (RPW) stages effected by parasite } & \multicolumn{2}{|c|}{ Mean } \\
\hline & Eggs & $\begin{array}{l}\text { Active } \\
\text { larvae }\end{array}$ & $\begin{array}{l}\text { Stages } \\
\text { inside } \\
\text { cocoons }\end{array}$ & $\begin{array}{l}\text { Parasite } \\
\text { carried } \\
\text { on adult }\end{array}$ & Total & $\begin{array}{c}\text { Temperature } \\
\mathbf{C}^{0}\end{array}$ & $\begin{array}{c}\text { Humidity } \\
\text { (RH) }\end{array}$ \\
\hline 15-Jan-2010 & 0.00 & 0.00 & 6.75 & 3.25 & 10.00 & 16.3 & 72.6 \\
\hline 31-Jan-2010 & 0.00 & 0.00 & 8.75 & 6.25 & 15.00 & 14.8 & 70.4 \\
\hline $15-F e b-2010$ & 0.00 & 0.00 & 8.75 & 4.00 & 12.75 & 16.3 & 69.5 \\
\hline 28-Feb-2010 & 0.00 & 0.00 & 8.25 & 4.00 & 12.25 & 16.2 & 64.9 \\
\hline 15-Mar-2010 & 0.00 & 0.00 & 37.75 & 16.00 & 53.75 & 19.9 & 67.9 \\
\hline 31-Mar-2010 & 0.00 & 0.00 & 19.50 & 10.75 & 30.25 & 17.0 & 67.6 \\
\hline 15-Apr-2010 & 0.00 & 0.00 & 14.75 & 5.25 & 20.00 & 19.1 & 66.2 \\
\hline 30-Apr-2010 & 0.00 & 0.00 & 11.75 & 4.25 & 16.00 & 23.3 & 62.9 \\
\hline 15-May-2010 & 0.00 & 0.00 & 8.00 & 4.25 & 12.25 & 23.5 & 61.1 \\
\hline 31-May-2010 & 0.00 & 0.00 & 8.75 & 3.00 & 11.75 & 23.9 & 62.3 \\
\hline 15-Jun-2010 & 0.00 & 0.00 & 8.75 & 5.50 & 14.25 & 26.0 & 60.1 \\
\hline 30-Jun-2010 & 0.00 & 0.00 & 7.00 & 4.75 & 11.75 & 25.8 & 60.7 \\
\hline 15-Jul-2010 & 0.00 & 0.00 & 4.75 & 0.75 & 5.50 & 27.1 & 61.9 \\
\hline 31-Jul-2010 & 0.00 & 0.00 & 3.25 & 0.25 & 3.50 & 28.6 & 62.9 \\
\hline 15-Aug-2010 & 0.00 & 0.00 & 2.00 & 0.25 & 2.25 & 28.2 & 62.9 \\
\hline 31-Aug-2010 & 0.00 & 0.00 & 2.25 & 0.50 & 2.75 & 29.9 & 63.7 \\
\hline 15-Sep-2010 & 0.00 & 0.00 & 6.50 & 0.75 & 7.25 & 26.9 & 64.0 \\
\hline 30-Sep-2010 & 0.00 & 0.00 & 7.50 & 1.25 & 8.75 & 27.3 & 63.8 \\
\hline 15-Oct-2010 & 0.00 & 0.00 & 6.00 & 0.75 & 6.75 & 26.8 & 62.8 \\
\hline $31-$ Oct-2010 & 0.00 & 0.00 & 4.50 & 1.75 & 6.25 & 23.6 & 63.2 \\
\hline 15-Nov-2010 & 0.00 & 0.00 & 6.25 & 2.25 & 8.50 & 22.3 & 63.8 \\
\hline 30-Nov-2010 & 0.00 & 0.00 & 11.50 & 6.00 & 17.5 & 21.3 & 63.1 \\
\hline 15-Dec-2010 & 0.00 & 0.00 & 5.75 & 0.75 & 6.50 & 16.1 & 64.2 \\
\hline 31-Dec-2010 & 0.00 & 0.00 & 10.00 & 2.50 & 12.50 & 15.7 & 62.2 \\
\hline total & & & 219 & 89 & 308 & 20.42 & 64.3 \\
\hline & & & 9.13 & 3.71 & 12.83 & & \\
\hline
\end{tabular}

Entomopathogenic fungus activity on (RPW) population.

Seasonal activity of pathogenic fungus on RPW population.

The seasonal appearance of naturally infected RPW (last larvae, pupae, adult) in cocoons and emergence adults with entomopathogenic fungus in response to RPW population was illustrated in Figure for the first and second year.

Data presented in Figure (7) showed the pathogenic fungus $B$. bassiana activity to attack RPW exhibited two seasonal periods of activity. The first period (2009) of activity started on the January till the May. The pathogenic fungus $B$. bassiana exhibited three peaks of seasonal activity. These peaks were recorded on the February (4\%), the March (4\%) and the May (4\%), respectively. While, the second season (2010), of activity was recorded from the January to the June and these peaks were recorded on the February (6\%), the April (6\%) and the May (14\%), respectively.

In spite of the RPW in cocoons population of $R$. ferrugineus was recorded with relatively high number infected by fungus $B$. bassiana and (active individuals were not diseased). Harmony with (SHarshir et al., 2006). 


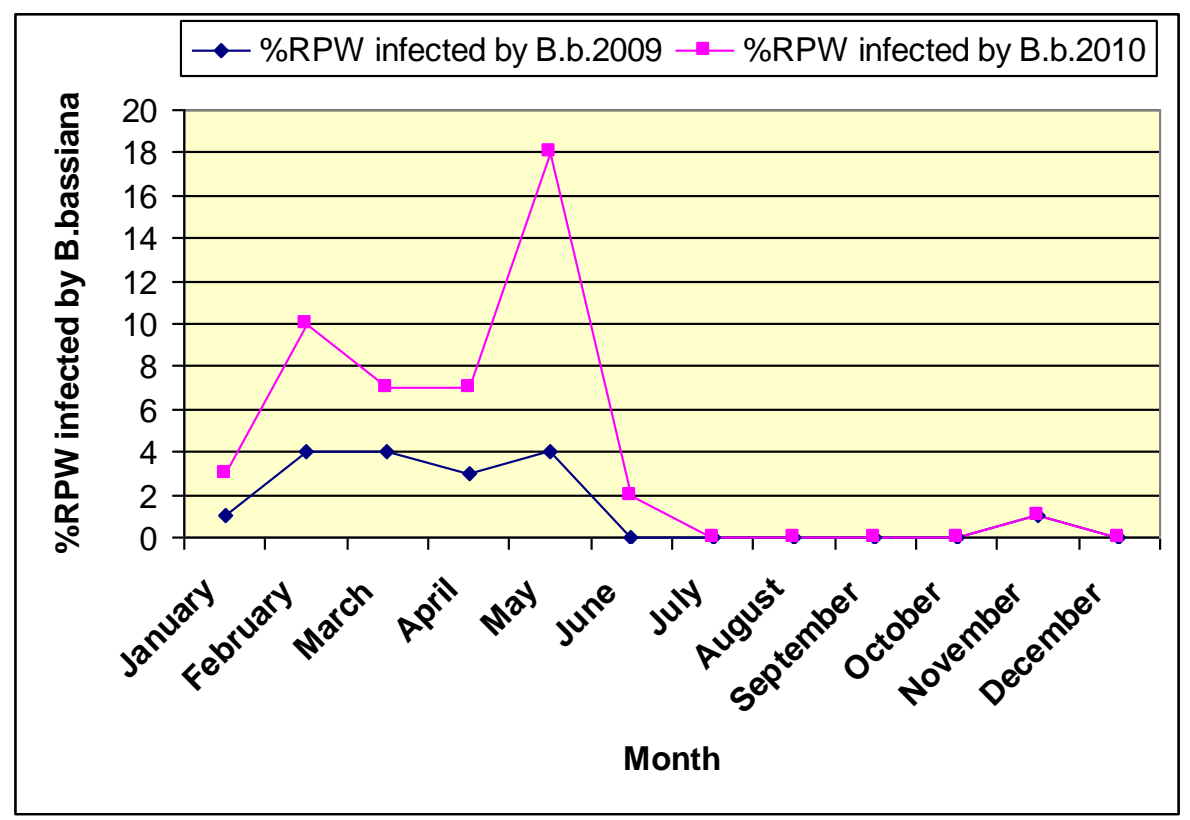

Figure (7). Seasonal activity of (RPW) fungal pathogens during seasons $2009-2010$ at Dakahlia governorate.

The effect of weather factors on activity of the fungus ( $B$. bassiana ) on red palm weevil $R$. ferrugineus Populations during 2009.

Data presented in Table (3)showed the fungus (B. bassiana ) on RPW is existed all over the year and there peaks all over the year 2009 , the mean of total high infected start with in the beginning of January then increased gradually to reach the first peak of February, March, April and May average $(4,4,3,4)$ respectably. Also it is law infection with highly temperature but negative with humidity, reason in palm high moister and rain in season winter. On the other hand period activity infected synchronization decreased activity (RPW).

Data presented in Table (4)showed the fungus ( $B$. bassiana )on RPW is existed all over the year and there peaks all over the year 2010 , the mean of total high infected start with in the beginning of January then increased gradually to reach the first peak of February, April and May (6, 4, 14) respectably. Also it is law infection with highly temperature but negative with humidity, reason in palm high moister and rain in winter season. On the other hand period activity infection synchronization decreased activity (RPW). 
Saleh, A. A. et al.

Table (3). Survey of $B$. bassiana from different infected palms with RPW during season 2009.

\begin{tabular}{|c|c|c|c|c|c|}
\hline \multirow[b]{2}{*}{ Survey date } & \multirow[b]{2}{*}{$\begin{array}{l}\text { No. of } \\
\text { insects }\end{array}$} & \multirow[b]{2}{*}{$\begin{array}{l}\text { No. of infected } \\
\text { insects }\end{array}$} & \multirow[b]{2}{*}{ Infection \% } & \multicolumn{2}{|c|}{ Mean } \\
\hline & & & & $\begin{array}{c}\text { Temperature } \\
\mathbf{C}^{0}\end{array}$ & $\begin{array}{c}\text { Humidity } \\
\text { (RH) }\end{array}$ \\
\hline $4^{\text {th }}$ Jan. & 400 & 4 & 1 & 12.6 & 60.3 \\
\hline $4^{\text {th }}$ Feb. & 200 & 8 & 4 & 12.8 & 61.2 \\
\hline $4^{\text {th }}$ Mar. & 200 & 8 & 4 & 14.7 & 59.5 \\
\hline $4^{\text {th }}$ Apr. & 400 & 12 & 3 & 20.7 & 64.0 \\
\hline $4^{\text {th }}$ May & 200 & 8 & 4 & 21.4 & 61.9 \\
\hline $4^{\text {th }}$ Jun. & 400 & 0 & 0 & 26.2 & 59.5 \\
\hline $4^{\text {th }}$ Jul. & 600 & 0 & 0 & 27.8 & 65.7 \\
\hline $4^{\text {th }}$ Aug. & 600 & 0 & 0 & 27.4 & 67.5 \\
\hline $4^{\text {th }}$ Sep. & 400 & 0 & 0 & 24.7 & 64.4 \\
\hline $4^{\text {th }}$ Oct. & 200 & 0 & 0 & 20.6 & 63.1 \\
\hline $4^{\text {th }}$ Nov. & 400 & 4 & 1 & 17.7 & 68.4 \\
\hline $4^{\text {th }}$ Des. & 400 & 0 & 0 & 15.7 & 69.2 \\
\hline
\end{tabular}

Table (4). Survey of B. bassiana from different infected palms with RPW during season 2010.

\begin{tabular}{|c|c|c|c|c|c|}
\hline \multirow[b]{2}{*}{ Survey date } & \multirow{2}{*}{$\begin{array}{l}\text { No. of } \\
\text { insects }\end{array}$} & \multirow{2}{*}{$\begin{array}{l}\text { No. of infected } \\
\text { insects }\end{array}$} & \multirow[b]{2}{*}{ Infection \% } & \multicolumn{2}{|c|}{ Mean } \\
\hline & & & & $\begin{array}{c}\text { Temperature } \\
\mathbf{C}^{0}\end{array}$ & $\begin{array}{c}\text { Humidity } \\
\text { (RH) }\end{array}$ \\
\hline $4^{\text {th }}$ Jan. & 400 & 8 & 2 & 15.5 & 71.5 \\
\hline $4^{\text {th }}$ Feb. & 200 & 12 & 6 & 16.3 & 67.4 \\
\hline $4^{\text {th }}$ Mar. & 200 & 6 & 3 & 18.4 & 67.7 \\
\hline $4^{\text {th }}$ Apr. & 400 & 16 & 4 & 21.2 & 64.4 \\
\hline $4^{\text {th }}$ May & 200 & 28 & 14 & 23.7 & 61.7 \\
\hline $4^{\text {th }}$ Jun. & 400 & 8 & 2 & 26.1 & 60.4 \\
\hline $4^{\text {th }}$ Jul. & 600 & 0 & 0 & 27.9 & 62.4 \\
\hline $4^{\text {th }}$ Aug. & 600 & 0 & 0 & 29.1 & 63.2 \\
\hline $4^{\text {th }}$ Sep. & 400 & 0 & 0 & 27.1 & 63.9 \\
\hline $4^{\text {th }}$ Oct. & 200 & 0 & 0 & 25.2 & 63.0 \\
\hline $4^{\text {th }}$ Nov. & 400 & 0 & 0 & 21.8 & 63.5 \\
\hline $4^{\text {th }}$ Des. & 400 & 0 & 0 & 15.9 & 63.4 \\
\hline
\end{tabular}

The comparing of the effect of the $B$. bassiana on different stages of (RPW) in laboratory:-

In general, the insecticidal activities of the tested microbial species against $R$. ferruginous treated as (RPW) stages are illustrated in Figures (8, $9,10,11,12,13,14$ and 15). However the regression lines expressing the potency against (RPW) eggs and adults pre emergence are showed in Figures (8and 14) it's clear that, B. bassaina exhibited the highest toxic effect against the (RPW) eggs and adult's pre emergence followed it pupae, larvae in cocoons, adult post emergence, last larvae and medium larvae. 
J. Plant Prot. and Path., Mansoura Univ., Vol. 4 (4), April, 2013

F8-9-10-11 
Saleh, A. A. et al.

F12-13-14-15

Predators activity in response to the red palm weevil population.

Found that, the Anisolobis maritime was the most numerous predator during the two seasons (2009-2010) of study.

The effect of degree of different infested palm by RPW on predator activity:

Monthly total numbers of the predaceous species which recorded on the infested palm degree, (new, medium, high) infestation of the date palm tree during the first and second 2009,2010 had been illustrated in Figure .

As shown in Figure (16), A. maritime was the most abundant predator with a total of $2.06 \%-5.76 \%, 27.16 \%$, and $65.02 \%$ individuals during control,( new, medium, high) infestation of the date palm tree , respectively. The highest peak of abundance was recorded on high infestation during season 2009 and 2010. The highest occurrence was 
observed on high infestation of the date palm tree (65.02\% individuals). The relationship between activity of the $A$. maritime and red palm weevil populations:

Data obtained during the year every month (2009-2010) indicated that when increased red palm weevil infestation increased number of predator eggs the $A$. maritime.

The obtained results obviously indicated that there are positive an association between the predators eggs $A$. maritime and their eggs of the $(R$. ferrugineus) populations. Showed the increased red palm weevil infestation and old infestation, increased the red palm weevil populations lead to egglaying of the weevil female, found that more number out trunk ,on cocoons and chewed-up tissues, no protection it eggs then lead to increased number of predator eggs the A. maritime. Sharaby and Al-Dosary(2010) carried out the adult A. maritime may be introduced in the future as a beneficial predator of eggs of R. ferrugineus as a tool for integrated pest management.

Verde et al (2008) mention that the long term it is hoped that natural enemies will emerge in infested areas to contain the species in its place of origin.

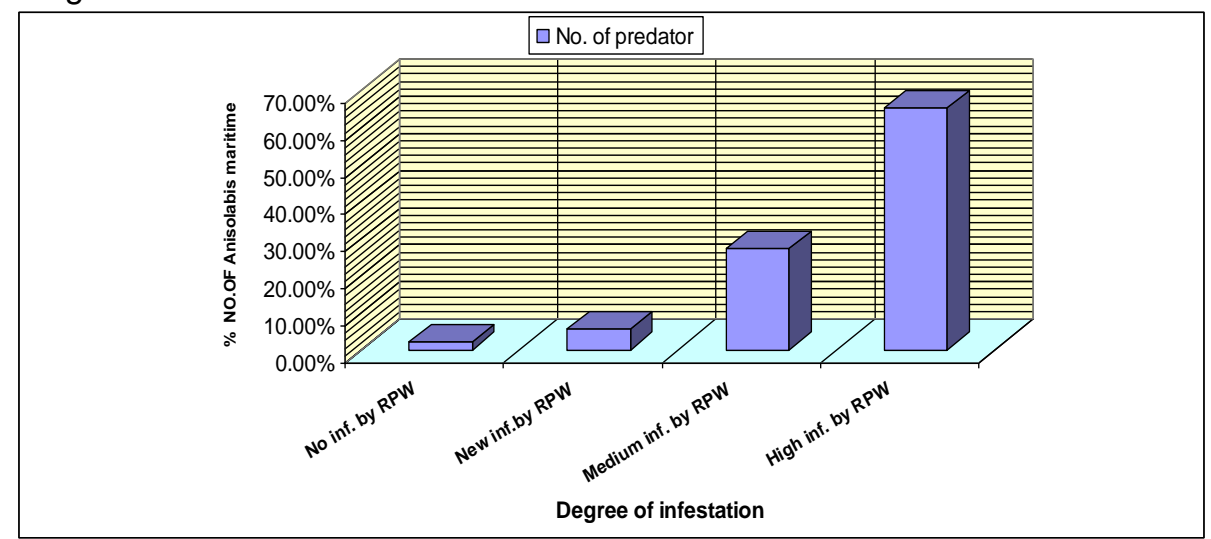

Figure (16).The effect of degree of different infested palm by RPW on predator activity.

\section{REFERENCES}

Abdullah, M .A. (2009). Biological control of the red palm weevil, Rhynchophorus ferrugineus (Olivier) (Coleoptera: Curculionidae) by the parasitoid mite, Rhynchopolipus rhynchophori (Ewing) (Acarina: Podapolipidae). J. Egypt Soc. Parasitol , 39(2):679-686.

Abraham, V.A.; M.A. AL Shuaibi; J.R. Faleiro; R.A. Abozuhairah and P.S. Vidyasagar (1998). An integrated management approach for red palm weevil, Rhynchophorus ferrugineus Olivi, a key pest of date palm in the Middle East.Proc . International Conf . , on integrated Pest management (Muscat, Sultanate of Oman). Sultan Qaboos Unic. J.Scient. Res. Argic.Sci., 3:77-83. 
Atakan, E.; S.Cobanoglu ; O.Yüksel and D. A. Bal (2009). Phoretic uropodid mites (Acarina: Uropodidae) on the red palm weevil [Rhynchophorus ferrugineus (Oliver, 1790) (Coleoptera: Curculionidae)].j. Türkiye Entomoloji. Dergisi., 33 (2) : 93-105.

Deadman,M.L.; K.M. Azam; S.A.Razvi; and W.Kaakah (2001 ).Preliminary investigations on the biological control of red palm weevil using Beauveria bassiana ( The second International Conference on Date palm held at the United Arab Emirates University , March. 2527,pp,225-232.)

Domsch,K.H.; W.Gams and T.H.Anderson (1980).Compendium of Soil Fungi. (v.1),Academic Press, 859PP.

EL-Bishlawy,SH.M.O and S.F.M.S.Allam (2007). Aegyptus rhynchophorus, N.GEN.,N.SP. (Acari:Uropodina: Trachyuropodidae) from the red palm weevil, rhynchophorus ferrugineus ( Olivier), (coleoptera, curculionidae)in Egypt. $2^{\text {th }}$ Pro. Inter Conf. Ent. Soc. Egypt, 1: 421-433.

El-Bishry, M. H.; Y. El-Sebay and M. H. Al-Elimi (2000). Impact of the environment in date palm infested with Rhynchophorus ferrugineus on five entomopathogenic nematodes (Rhabditida). International. J. of Nematology, 10 (1): 75-80.

EL-Lakwah, F.A.M; A.A.EL-Banna; R.A.EL-Hosary and W.K.M. EL-Shafei (2011). Population dynamics of the red palm weevil( Rhynchophorus ferrugineus(oliv)on date palm plantations in 6 th $^{\text {October }}$ governorate.Egypt.j.Agric. Res., 89(3):1105-1118.

FAO (1996). Code of conduct for the import and releas of exotic biological control agents. (International Standards for Phytosanitary Measures ( ISPM) Publication No. 3,Rome, Italy).

Henderson,c. and W.F.Tilton (1952).Test with acarides against the brown mite. J.Econ. Entomol., 48:157-161.

Kalshoven, L.G.E. (1950). Pests of Crops in Indonesia , P.T.1chatiar BaruVan Hoeve, Jakarta. Revised and translated by P.A. Van der Laan., 1988.,190.

Mazza,G.; A.Cini ; R.Cervo and S.Longo(2011). Phoresy, Just? Reduced lifespan in red palm weevils Rhynchophorus ferrugineus (Coleoptera: Curculionidae) infested by the mite Centrouropoda almerodai (Uroactiniinae: Uropodina).J. \& Zoology ,78(1) :214-221.

Mazza, G .; V. Arizza; B. David ;G. P. Barzanti ; B . Claudia ; F. Valeria ; F. Antonio; G. Francesca; L. Santi; M. Barbara; P. Brunella; R. Pietro; S. Domenico ; T. Stefano and C. Rita (2011). Antimicrobial activity of the red palm weevil Rhynchophorus ferrugineus. Bulletin of Insectology , 64 (1): 33-41, ISSN 1721-8861.

Murphy,S.T. and B.R.Briscoe ( 1999 ).The red palm weevil as an alien invasive :biology and the prospects for biological control as component of IPM. Biocontrol news and information ,20(1):35-46.

Peter, C. (1989). A note on the mites associated with the red palm weevil, Rhyncophorus ferrugineus Oliv. in Tamil Nadu. Journal-of-InsectScience. [J. INSECT SCI.]., 2 (2): 160-161. 
Rahalkar, G. and H.Ranavacare (1972).Development of red palm weevil, Rhynchophorus ferrugineus Olivi. On sugarcane. Indian. J.Ent., 34:213-215.

Sewify, G. H.; M. H. Belal and S. A. Al-Awash (2009). Use of the entomopathogenic fungus, Beauveria bassiana for the biological control of the red palm weevil, Rhynchophorus ferrugineus Olivier. J . Egyptian Journal of Biological Pest Control , 19 (2): 157-163.

Sharaby, A. and M. M. Al-Dosary (2010). Ultra morphology of sensilla on the head and mouth parts of the earwig Anisolabis martima (Bonelli) (Dermaptera: Carcinophoridae). Archives of Phytopathology and Plant Protection. J. article, 43 (12): 1214-1224.

SHarshir,F.A. ;R.A.Ibrahim; and SH.M.A. EL-Gremi(2006). Infestation rates of date palm by the red palm weevil, (Rhynchophorus ferrugineus)oliver and its associated natural enemies at Balteem, Kafr EL-Sheikh, Egypt.Bull.Ent.Soc. Egypt, 83:327-336.

Soroker, V.; D.Blumberg; A.Hamberman; M.Hamburger-Rishard; S.Reneh and S.Talebaev (2005). Current status of red palm weevil, infestation in date palm plantations in Israel. Phytoparasitica, 33:97-106.

Verde, G. L.; C. G. Caldarella; G. la. Mantia and G.Sauro(2008). Continues to emerge. Informatore Agrario. J. article , 64 (10): 74-77.

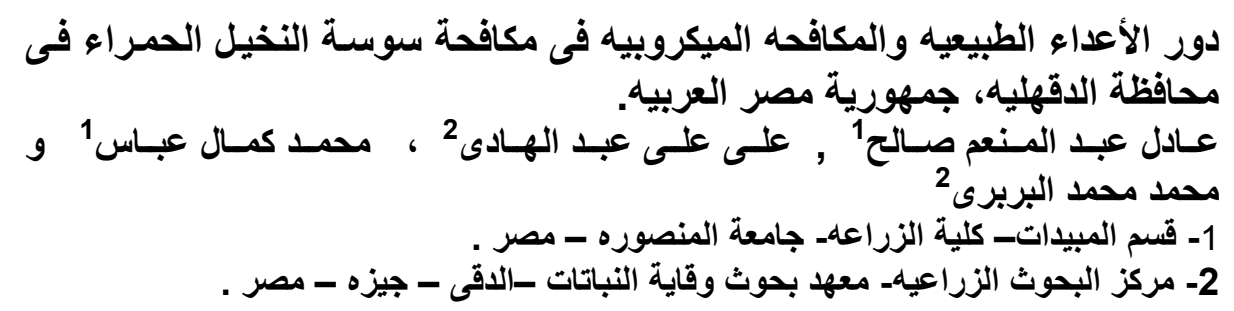

أجريت هذه الدراسـه على النخيل المصـاب بسوسـة النخيل الحمر اء بمحافظة الدقهليه

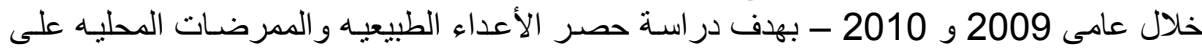

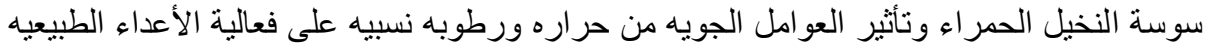

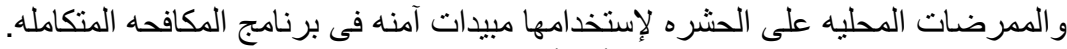

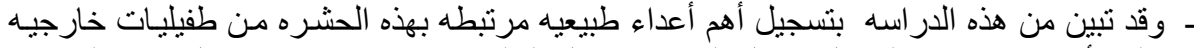

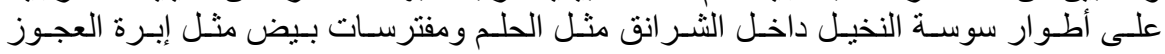

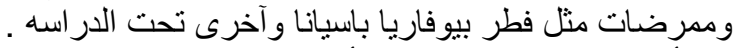

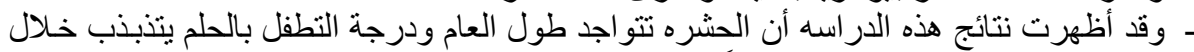

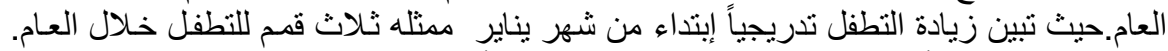

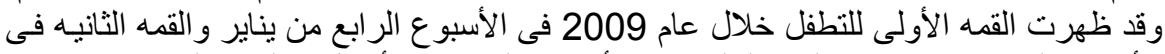

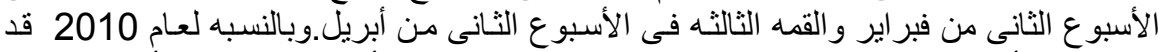

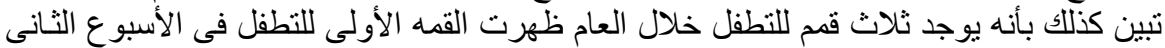

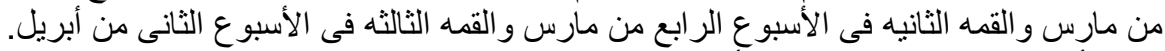

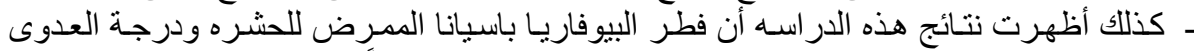

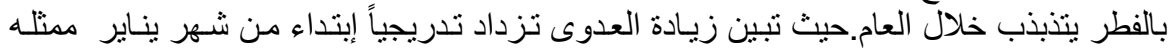

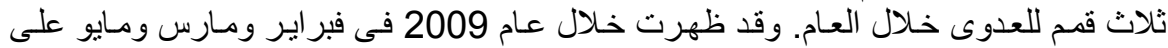

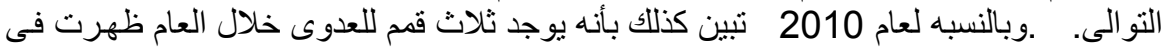




\section{Saleh, A. A. et al.}

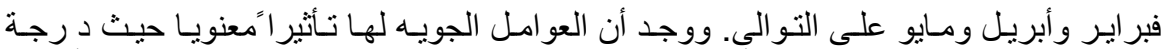

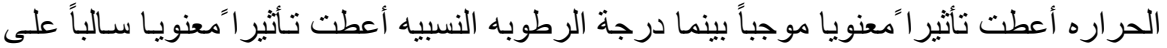

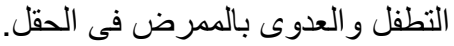

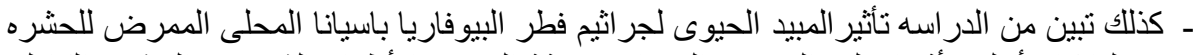

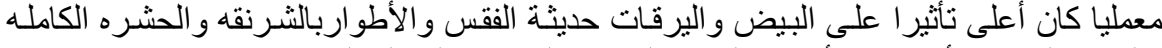

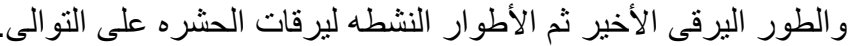

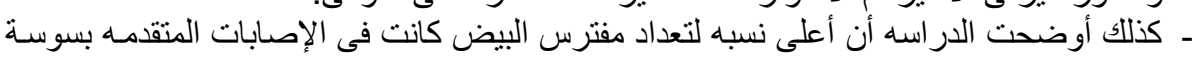

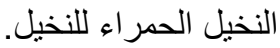

كلية الزراعة - جامعة المنصورة

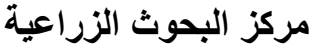

$$
\text { قام بتحكيم البحث }
$$

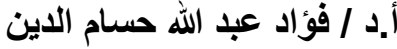

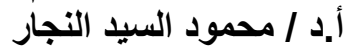

